\title{
HEALTH PROMOTION IN PUBLIC OUTREACH PROGRAMS OF A BRAZILIAN PUBLIC UNIVERSITY
}

\section{David Michel de Oliveira, ${ }^{2}$ Gisélia Gonçalves de Castro, ${ }^{3}$ Ana Paula Freitas Vilela Boaventura, ${ }^{4}$ Kamylla Caroline Santos and ${ }^{5}$ Edlaine Faria de Moura Villela}

${ }^{1}$ Doctor in Foods and Nutrition from São Paulo State University (UNESP), Brazil; ${ }^{2}$ Postdoctoral researcher from the Health Promotion Postgraduate Programof the Universityof Franca (UNIFRAN), Brazil; ${ }^{3}$ Master and Doctor in Mechanical Engineering fromthe Federal University of Uberlândia (UFU), Brazil; ${ }^{4}$ Postgraduate student in Animal Bioscience from the Federal University of Jataí (UFJ), Brazil; ${ }^{5}$ Doctorin Epidemiology from the School of

Public Health of the University of São Paulo (USP), Brazil

\section{ARTICLE INFO}

Article History:

Received $18^{\text {th }}$ February, 2020

Received in revised form

$22^{\text {nd }}$ March, 2020

Accepted $17^{\text {th }}$ April, 2020

Published online $25^{\text {th }}$ May, 2020

\section{Key Words:}

Promotion. Health. Strategies.

Education. Training.

*Corresponding author: Ana Caroline Guedes Souza Martins,

\begin{abstract}
Health promotion as a field of knowledge combined with public outreachprograms is a differential in training health professionals, strategic for social action and humanized care. This study aimed to identify the outreach programs carried out at a public university in Central-West Brazil andverify their useof health promotion concepts. This documentary researchcollected datainthe electronic platformaccessing the university's portal, surveying allprojects registered in 2017. Unfinished actions were excluded. To determine the total number of programs, duplicated ones were identified and counted once. There were 23outreach programs registered and carried out, presenting the partial and final reports required by the university. Of these, $40 \%$ were from the Nursing program. Health promotion concepts were present in $60 \%$ of the projects, while theNational Health Promotion Policy was mentioned in $16 \%$ of them. In conclusion,it is necessary to change the students' training model and include public outreach programs focusing on health promotion as an integral part of the pedagogical projects of the university'scurricula. Hence, they should be mandatory activities and no longer extracurricular ones, promoting social responsivity during training in health.
\end{abstract}

Copyright $($ C 2020, David Michel de Oliveira et al. This is an open access article distributed under the Creative Commons Attribution License, which permits unrestricted use, distribution, and reproduction in any medium, provided the original work is properly cited.

Citation: David Michel de Oliveira, Gisélia Gonçalves de Castro, Ana Paula Freitas Vilela Boaventura, Kamylla Caroline Santos and Edlaine Faria de Moura Villela, "Health promotion in public outreach programs of a Brazilian public university", International Journal of Development Research, 10, (05), 35518-35523.

\section{INTRODUCTION}

Integrating education, research, and public outreach can turn a university into a health-promoting institution that intervenes in complex and multidetermined social problems. Health promotion is a theoretical-methodological formulation whose focus is on the multiple complex determinations involved in the health-disease process and the need for interdisciplinary and intersectoral actions (Monnerat and Souza, 2011). Based on the recommendations and intentions of the main international conferences on health promotion, Figueiredo and Martins (2016) point out important aspects of this concept. The increase in the individuals' and groups' capacity to control their health and improve their quality of life is an important element. The persons and communities must be capable of identifying their needs and aspirations and ensure that society provides the means for each of its members to achieve both the quality of life and well-being. Thus, there is an emphasison social, economic, and environmental health determinants, demonstrating that health promotion must articulate intersectoral actions and aim at social responsibility in health (Povlsen and Borup, 2015). It is believed that health promotion as a public health field of knowledge allied to public extension programs can add to the health professional's training since it is a social action strategy with humanized care. Therefore, understanding its concepts as well as its applicability in professional practice are considered relevant study objects (Liveng et al., 2018). University public outreach is an important factor in the student's training because it both broadens their scope of reference and provides direct contact with major present-day issues. Hence, the student's experience is enriched in theoretical and methodological terms, while the ethical commitments of Brazilian public universities are reaffirmed and materialized (FORPROEX, 2015). In this regard, this study aims to verify whether the extension projects of the health programs at the Federal University of Jataí (UFJ), in Goiás, Brazil, make use of health promotion theoretical concepts. If that is the case, the concepts used will be exposed, investigating whether these concepts converged in between the various projects analyzed. The goal is to verify if academic 
training in health is in harmony with the studies that broaden the understanding of the health-disease-process and how such knowledge is being assimilated by the community through public outreach programs. Based on documentary analysis, the profile of public health outreach programs that have already been put into practice will be described. Thus, the great importance of considering such profiles as assessing instruments and as a basis for proposing other public outreach programs developed by the university. Therefore, this paper's objective is to outline public health outreach programs of a Brazilian public university, focusing on the approach to health promotion concept as a theoretical reference of the actions proposed during the time of the study.

\section{MATERIALS AND METHODS}

This study is designed as a documentary descriptive research. The documentary analysis seeks to identify factrelatedinformation in original documents that were not yet analyzed, based on questions and hypothesis of interest (SáSilva et al., 2009). The study was conducted based on the following research questions: The programs in the field of health at the UFJ have the broadened concept of health as one of the principles in their pedagogical framework and public outreach programs. Hence, what are the outlines of the public outreach programs put into practice? Do they use as theoretical reference the health promotion concepts as well as the National Health Promotion Policy(PNPS)?

\section{Procedures and eligibility criteria}

Data was collected from university programs of the Health Sciences Unit (CISAU) that conducted public outreach programs in 2017. The search was made in the electronic platform by accessing the UFGNet portal and browsing the publicdomain Academic Activities Management Integrated System tab (SIGAA) https://sigaa.sistemas.ufg.br/sigaa/public/extensao/consulta_ex tensao.jsf. The search and analysis were based on all the projects registered, formalized, and conducted in 2017, whose partial and final reports were presented. Actions that were registered but not put into practice were excluded. To count the total actions, duplicated ones were identified and considered only once. The analysis was based on the actions included. The information used to categorize the selected studies was their title, program of origin, type of action, the field of outreach, purpose, number of university/community participants, and support received. Moreover, it was identified whether they had used the concept of health promotion, as well as the PNPS regulations as theoretical reference.

\section{RESULTS}

A total of 37 public outreach programs carried out in the period of study were identified. Of these, 23 met the eligibility criteria - having been registered and carried out, with partial and final reports. The public outreach programs, as well as the university program that proposed them, are presented in Table 1. It is noted that Nursing promoted $40 \%$ of the public outreach programs carried out in 2017. Regarding the type of action promoted, $80 \%$ were public outreach projects. As for the field, human health and continuing education were the themes the coordinators described the most. Concerning the purpose, $52 \%$ of the outreach programs aimed at health education (Table 2).
Table 1. Public outreach programs carried out by the Health Sciences Unit of the Federal University of Jataí, Brazil

\begin{tabular}{|c|c|}
\hline Title of outreach program & University program \\
\hline $\begin{array}{l}\text { 1. Antimicrobial properties of plants used } \\
\text { in popular medicine }\end{array}$ & Biomedicine \\
\hline $\begin{array}{l}\text { 2. Recreational activities for elderly } \\
\text { inpatients }\end{array}$ & Physical Education \\
\hline 3. Working out on campus & Physical Education \\
\hline 4. II Round of Debates on Physical & Physical Education \\
\hline \multicolumn{2}{|l|}{ Education and PIBID } \\
\hline Community health education & Physical Education \\
\hline 6. Group fitness training in the university & Physical Education \\
\hline 7. Aquatic community & Physical Education \\
\hline 8. Adolescence and sexual awakening & Nursing \\
\hline $\begin{array}{l}\text { 9. Diabetic feet: Examination and basic } \\
\text { educational guidelines }\end{array}$ & Nursing \\
\hline 10. $9^{\text {th }}$ Nursing Week at theFederal & Nursing \\
\hline University of Goiás, campus of Jataí - "Good & \\
\hline $\begin{array}{l}\text { Nursing Practices and the Development of a } \\
\text { Democratic Society" }\end{array}$ & \\
\hline $\begin{array}{l}\text { 11. Good Morning, SUS: information, } \\
\text { health, and citizenship }\end{array}$ & Nursing \\
\hline $\begin{array}{l}\text { 12. Green April: Patient safety in nursing - } \\
\text { an action of REBRAENSP }\end{array}$ & Nursing \\
\hline 13. More welcoming: freshman reception & Nursing \\
\hline $\begin{array}{l}\text { 14. Lenses for gender: children's and } \\
\text { adolescents' creativity at school }\end{array}$ & Nursing \\
\hline $\begin{array}{l}\text { 15. Evaluation and prevention of } \\
\text { cardiovascular disease risk behaviorin } \mathrm{Dr}\end{array}$ & Nursing \\
\hline
\end{tabular}

cardiovascular disease risk behaviorin Dr.
Serafim de Carvalho Clinical Hospital's workers and inpatients

16. Expanding communication between the Physical therapy

Physical Therapy program and the

community

17. Stomatological DiagnosticOutpatient Center of Southwestern Goiás (ADESGO)

18. Medicine\& Art: connecting with life

19. Psychological follow-up of patients

submitted to biopsy: waiting for a mouth cancer diagnosis

20. Literature, Cinema, Radio and Digital

Inclusion for the Community: In search of an

interdisciplinary and humanized academic

training

21. Association between arterial pressure

level and occurrence of infections in women

from 40 to 60 years old in the municipality of Jataí, Goiás

22. Participating in the GraduaSUS Practical

Training Program- Medicine in re-

developingmedical training practices

23. Mentoring Group: Re-signifying the

academic mismatches during medical

training

Legend: PIBID - Institutional Scholarship Program for Undergraduate Educational Research; SUS - Unified Health Care System (Brazil's publicly funded health care system); REBRAENSP - Brazilian Network of Nursing and Patient Safety

Note: The actions are numbered for easy identification in the following tables. Source: SIGAA/UFGNET, 2017.

Regarding the university public (professors, students, and administration personnel) involved in the staff that carried out the actions, Medicine was the program with the most participation, with a total of 123 people. The community, in its turn, as the target audience of the outreach programs, Nursing reached the most people when all the actions are added; Physical Therapy, on the other hand, reached the most in a single action, approximately 1,000 people. Only $21 \%$ of them counted with funding, as seen in Table 3.

Health promotion was present as a concept in $60 \%$ of the outreach program's description registered and carried out in 2017 (Table 4). ThePNPS regulations were mentioned as a scientific reference in $16 \%$ of the actions. 
Table 2. Categorization of the public outreach programs by university program, type of action, field, and purpose - Health Sciences Unit of the Federal University of Jataí, Brazil

\begin{tabular}{|c|c|c|c|c|}
\hline Number of the action, as in Table 1 & University program & Type of action & Outreach field & Purpose \\
\hline 1 & Biomedicine & Project & Human Health & Clinico-experimental \\
\hline 2 & Physical Education & Project & Human Health; Older Adults & Intervention \\
\hline 3 & Physical Education & Project & Sports and Leisure & Intervention \\
\hline 4 & Physical Education & Event & Continuing Education & Health Education \\
\hline 5 & Physical Education & Project & People with Special Abilities & Health Education \\
\hline 6 & Physical Education & Project & Sports and Leisure & Intervention \\
\hline 7 & Physical Education & Project & Sports and Leisure & Intervention \\
\hline 8 & Nursing & Project & Childhood and Adolescence & Intervention \\
\hline 9 & Nursing & Project & Human Health & Health Education \\
\hline 10 & Nursing & Event & Continuing Education & Health Education \\
\hline 11 & Nursing & Project & Continuing Education & Health Education \\
\hline 12 & Nursing & Course & Continuing Education & Health Education \\
\hline 13 & Nursing & Event & Strategic Communication & Health Education \\
\hline 14 & Nursing & Project & Childhood and Adolescence & Health Education \\
\hline 15 & Nursing & Project & Continuing Education & Intervention \\
\hline 16 & Physical Therapy & Project & Information Management and medias & Data Survey \\
\hline 17 & Medicine & Project & Human Health & Diagnosis \\
\hline 18 & Medicine & Project & Human Health; Performing Arts & Health Education \\
\hline 19 & Medicine & Project & Human Health & Clinical \\
\hline 20 & Medicine & Project & Media, Human Health, andDevelopment & Health Education \\
\hline 21 & Medicine & Project & Human Health & Epidemiological \\
\hline 22 & Medicine & Project & Continuing Education & Health Education \\
\hline 23 & Medicine & Project & Human Health & Intervention \\
\hline
\end{tabular}

Source: SIGAA/UFGNET, 2017.

Table 3. Number of the action, number of participants (university/community), and project funding of the public outreach actions carried out at the Health Sciences Unit of the Federal University of Jataí, Brazil

\begin{tabular}{|c|c|c|c|c|}
\hline Number of the action, as in Table 1 & University program & University participants & Community participants & Funding \\
\hline 1 & Biomedicine & 5 & ND & YES \\
\hline 2 & Physical Education & 10 & 20 & NO \\
\hline 3 & Physical Education & 12 & 80 & NO \\
\hline 4 & Physical Education & 20 & ND & NO \\
\hline 5 & Physical Education & 5 & 200 & NO \\
\hline 6 & Physical Education & 5 & 80 & NO \\
\hline 7 & Physical Education & 2 & 60 & NO \\
\hline 8 & Nursing & 8 & 800 & NO \\
\hline 9 & Nursing & 10 & 300 & NO \\
\hline 10 & Nursing & ND & 278 & $\mathrm{NO}$ \\
\hline 11 & Nursing & ND & 200 & $\mathrm{NO}$ \\
\hline 12 & Nursing & ND & 233 & NO \\
\hline 13 & Nursing & 10 & 28 & $\mathrm{NO}$ \\
\hline 14 & Nursing & 10 & 45 & YES \\
\hline 15 & Nursing & 8 & ND & YES \\
\hline 16 & Physical Therapy & 8 & 1000 & YES \\
\hline 17 & Medicine & 10 & 500 & $\mathrm{NO}$ \\
\hline 18 & Medicine & 50 & 400 & $\mathrm{NO}$ \\
\hline 19 & Medicine & 6 & ND & $\mathrm{NO}$ \\
\hline 20 & Medicine & 22 & 600 & $\mathrm{NO}$ \\
\hline 21 & Medicine & 13 & 100 & $\mathrm{NO}$ \\
\hline 22 & Medicine & 8 & 200 & YES \\
\hline 23 & Medicine & 14 & 40 & $\mathrm{NO}$ \\
\hline
\end{tabular}

\section{DISCUSSION}

Based on the documentary analysis of the public outreach programs carried out at CISAU/UFJ, the scenario of actions and their relationship directly or indirectly established with health promotion was dimensioned. According to the Ministry of Science and Technology, social development is one of the most important aspects of the current state policies. This social policy is what ensures that more social development equity is achieved, overcoming the difficulties and investing in necessary projects, programs, and actions (Soares, 2012; Marques et al., 2019). University public outreach programs are included in these as an interdisciplinary, educative, cultural, scientific, and political process, which involves transforming interaction between the university and other sectors of society.
One of its principles is the need to integrate popular knowledge with academic-scientific knowledge. Hence, the university, especially the public ones, are responsible for bringing about social changes and transformations (Soares, 2012; Guerra and Kurtz, 2017). The higher education institutions are being encouraged to modify their training process to respond to this social need so that the graduates in the field of health can have a critical and reflexive understanding of the reality in which they are being inserted (Fernandes et al., 2013). In this sense, the Nursing program is of an inherently political, conceptual, and practical nature, as it thinks and acts along with the population. Their practice must be based on social health determinants, with the commitment of thinking and acting together with the people, focusing on the social health determinants to produce social interventions 
Table 4. Health promotion as an underlying concept, andthe National Health Promotion Policy document as a citation and scientific reference in the public outreach actions at the Health Sciences Unit of the Federal University of Jataí, Brazil

\begin{tabular}{|c|c|c|c|}
\hline Number of the action, as in Table 1 & University program & Health Promotion concept & Citation/referenceto PNPS \\
\hline 1 & Biomedicine & $\mathrm{NO}$ & $\mathrm{NO}$ \\
\hline 2 & Physical Education & NO & NO \\
\hline 3 & Physical Education & NO & NO \\
\hline 4 & Physical Education & $\mathrm{NO}$ & $\mathrm{NO}$ \\
\hline 5 & Physical Education & YES & YES \\
\hline 6 & Physical Education & YES & NO \\
\hline 7 & Physical Education & YES & NO \\
\hline 8 & Nursing & YES & $\mathrm{NO}$ \\
\hline 9 & Nursing & YES & NO \\
\hline 10 & Nursing & YES & NO \\
\hline 11 & Nursing & YES & YES \\
\hline 12 & Nursing & $\mathrm{NO}$ & $\mathrm{NO}$ \\
\hline 13 & Nursing & NO & NO \\
\hline 14 & Nursing & YES & NO \\
\hline 15 & Nursing & YES & $\mathrm{NO}$ \\
\hline 16 & Physical Therapy & NO & NO \\
\hline 17 & Medicine & YES & $\mathrm{NO}$ \\
\hline 18 & Medicine & YES & YES \\
\hline 19 & Medicine & YES & NO \\
\hline 20 & Medicine & YES & YES \\
\hline 21 & Medicine & $\mathrm{NO}$ & $\mathrm{NO}$ \\
\hline 22 & Medicine & $\mathrm{NO}$ & $\mathrm{NO}$ \\
\hline 23 & Medicine & NO & NO \\
\hline
\end{tabular}

Source: SIGAA/UFGNET, 2017.

that contribute to effective equity (Fernandes et al., 2018). In this paper, the Nursing program was perceived as promoting most of the outreach programs and reaching the greatest number of people. Oliveira and Almeida Junior (2015) analyzed the benefits brought by public outreach programs to academic training, according to the perception of Nursing students from the Federal University of Rio Grande do Norte (FACISA/UFRN). It was identified that the outreach programs were developed with different approaches, from assistive methods to the practice of what was learned in the classroom. The university public outreach programs are carried out in different manners, such as professional training courses, internships, attention given directly to the community, participating in cultural initiatives, study and research on aspects of the local or regional reality, promoting artistic and cultural activities, sharing knowledge, stimulating artistic, scientific and technological creativity, and others (Melo Neto, 2002). Most of the actions researched in this paper were projects. In this regard, the university, besides training its students, must at the same time share its knowledge with the outreach's target-audience, which justifies the outreach projects' becoming more emphasized in the programs when compared to other outreach formats (Soares, 2012). The process of organizing public outreach programs - which can be conducted by outreach committees, whose purpose is to debate and develop the policies as social work within the university - has varied possibilities (Melo Neto, 2002). In this sense, the most mentioned themes in the projects, after having been discussed in the committees, were human health and continuing education. The World Health Organization (WHO) defines health as not only the absence of disease but also the condition of perfect physical, mental and social well-being, reflecting the social, economic, political, and cultural situation. In other words, health does not mean the same to everyone. It depends on social class, individual values, and scientific, religious, and philosophical concepts (Segre and Ferraz, 1997; Scliar, 2007). This context should be part of every health professional's training since they need to be trained as critical and reflexive subjects involved with social reality. Hence, the university outreach programs are dynamic and effective means of interaction between the student and the society, developing the cultural, scientific, and educational process (Ponte et al., 2009). They must be understood as an integral part of university curricula, and not only as an optional extracurricular activity, considering that, in face of the requirements presented by the current National Education Plan (PNE), the low percentage of undergraduate students participating in public outreach programs is worrying (Nascimento et al., 2018). Continuing education started in England in the second half of the $19^{\text {th }}$ century with coursed for the adult population (Tavares et al., 2007). It is noticed, then, that continuing education is the basis of university outreach ever since its beginnings, especially in health-related courses, whose continuous learning leads to personal and professional growth, reflecting on the quality of the assistance given to people (Falkenberg et al., 2014). Thus, university outreach programs enable the student to discover new learning resources and develop the skills and competencies, essential to human interaction. Consequently, the students are inserted increasingly earlier in the communities, making the university outreach programs an important channel for communication and interaction between the university and the society where it is located (Loyola and Oliveira, 2005; Oliveira and Almeida Junior, 2015).

Most of the public outreach programs aimed at health education - which is understood as a set of practices and knowledge whose purpose is to prevent diseases and promote health, offering the means for people to adopt habits that will improve their life as they understand daily factors related to the health-disease process (Silva et al., 2007). Therefore, health professionals must be prepared with both an effective theoretical basis and enhanced attitudes, values, and competencies. Thus, health professionals will truly promote the population's health, not conceiving health education as only instructing and teaching how to prevent diseases (Pereira et al., 2015). The Medicine program had the greatest number of people involved in carrying out public outreach programs. They are more involved in such actions as a training strategy, looking for new scenarios for the students to learn to work with the community, ensuring a differentiated and humanized 
training, committed to the social concept of health (Sobrinho et al., 2005) and social responsivity. The Physical Therapy program was the one with the greatest number of people in a single action, which was announced through social media, leading to an integration with the community - therefore, they reached such a great number of people in one action. Skura et al. (2013) reported that social media were used as communication technology to promote health in a group of older adults in a public outreach program and verified that this method integrated a greater number of people when compared to projects that did not use such means. In Brazil, university outreach programs appear along with higher education itself, in the $20^{\text {th }}$ century. The first occurrences took place in the courses and conferences of the old University of São Paulo, in 1911, and the services offered by the Higher Education School of Agriculture and Veterinary of Viçosa developed in the 1920s. In 1970, the Ministry of Education and Culture (MEC) and the Ministry of the Interior created the Mixed Commission CRUTAC/MEC -Extension Campus/MINTERto propose measures to institutionalize and strengthen university outreach programs. In this context, the creation of the Coordination for Outreach Activities (CODAE) in 1974 is particularly important (FORPROEX, 2015).

The Constitution of 1988 regulates the "inseparability between education, research, and public outreach", determining that the State may be a source of financial support of university research and outreach activities (FORPROEX, 2015). However, the results of this study indicate that only $21 \%$ of the actions received any funding. University outreach programs, under the constitutional principle of inseparability between education, research, and outreach, is an interdisciplinary, educative, cultural, scientific, and political process that promotes the transforming interaction between the university and other sectors of society. Furthermore, strengthening university outreach programs depends on changes in their funding process, to ensure the necessary quantitative increase of resources, their improved stability, solidity, and transparency, and their focus on priority areas (FORPROEX, 2015). Understanding public outreach actions leads to the reflection on the importance of training the individuals essentially as one who promotes quality of life (Skura et al., 2013). Thus, the principles of primary health care end, considering the individual in their uniqueness, complexity, integrity, and sociocultural context through prevention of diseases, with actions encouraging social participation, promoting healthy environments, developing intersectoral actions, developing public policies to improve the organization of health services and the living conditions of individuals and populational groups. Moreover, these actions must always be guided by the principles of universality, accessibility, continuity, comprehensiveness, responsibility, equity, humanization, bonding, and social participation (CONASS, 2007; Medina et al., 2014; Shimazaki, 2009).

The concept of health promotion was mentioned in $60 \%$ of the public outreach programs, whereas the PNPS regulations were mentioned as a scientific reference in only $16 \%$ of them. According to WHO, health promotion can be identified in programs, policies, and activities, being developed and carried out through the principles of holistic concepts, intersectorality, empowerment, social participation, equity, multi-strategic actions, and sustainability (WHO, 1998). In 2006, the Ministry of Health, the National Council of the State Departments of Health (CONASS), and the National Council of Municipal
Departments of Health (CONASEMS) developed and approved the PNPS (Malta and Castro, 2009). The purpose of these policies is to promote the quality of life and diminish the vulnerability and health risks related to lifestyle, working conditions, housing, environment, leisure, culture, and access to essential goods and services (BRASIL, 2010).

\section{Conclusion}

This study enabled the analysis of the public outreach programs from CISAU/UFJ carried out in 2017, to verify and confirm the harmony between academic training in health and the understanding of the health-disease process regarding health promotion, quality of life and well-being. Moreover, there was harmony and interaction between the university and the community participating in the outreach programs. The results of this paper furnished a better understanding of the university outreach events, as well as the identification of relevant adjustments in the registry of such actions and in the system itself. Based on the analysis, these students' training model needs some changes, to include public outreach as an integral part of the pedagogical projects of the program, making them mandatory activities instead of extracurricular ones, as they currently are - this agrees with the proposal of including the outreach programs in the university curricula. It is increasingly necessary to offer to undergraduate students in the field of health the opportunity of being active interlocutors in the process of developing health promotion awareness in all fields of knowledge.

\section{REFERENCES}

Brasil (2010). Ministério da Saúde. Secretaria de VigilânciaemSaúde. Secretaria de Atenção à Saúde. Política Nacional de Promoção da Saúde / Ministério da Saúde, Secretaria de VigilânciaemSaúde, Secretaria de Atenção à Saúde. - 3. ed. - Brasília: Ministério da Saúde.

ConselhoNacional de Secretários de Saúde (CONASS) (2007). Programa de Informação: apoiotécnicoà sequipesgestorasestaduais do SUS. Atençãoprimária e promoção da saúde. Conass.

Falkenberg MB, Mendes TPL, Moraes EP, Souza EM (2014). Educaçãoemsaúde e educaçãonasaúde: conceitos e implicações para a saúdecoletiva. CienSaude Colet, 19(3):847-852.

Fernandes JD, Silva RMD, Teixeira GA, Florencio RMS, Silva LS, Rebouças LCC (2013). Aderência de cursos de graduaçãoemenfermagemàsdiretrizescurricularesnacionais naperspectiva do sistemaúnico de saúde. Esc Anna Nery. 17(1):82-9.

Fernandes MC, Silva LMS, Silva MRF, Torres RAM, Dias MSA, Moreira TMM (2018).Identidade do enfermeironaatençãobásica: percepção do "faz de tudo". Rev Bras Enferm, 71(1):154-9.

Figueiredo GLA, Martins CHG (2016). Políticas, tecnologias e práticasempromoção da saúde. Franca: UNIFRAN, São Paulo: Hucite.

FORPROEX -Encontro de Pró-Reitores de Extensão das UniversidadesPúblicasBrasileiras(2012). Manaus. Política Nacional de ExtensãoUniversitária. Disponívelem: $<$ https://proex.ufsc.br/files/2016/04/Pol\%C3\%ADticaNacional-de-Extens \%C3\%A3o-Universit\%C3\%A1ria-ebook.pdf $>$.

Guerra O, Kurtz D (2017). Building collaboration: a scoping review of cultural competency and safety education and 
training for healthcare students and professionals in Canada. Teach Learn Med 29(2):129-42.

Liveng A, Andersen HM, Lehn-Christiansen S (2018). Health promotion in context: A reflective-analytical model. Scand JPublic Health, 46(20):66-71. SAGE Publications. http://dx.doi.org/10.1177/ 1403494817743899

Loyola CMD, Oliveira RMP (2005). A universidade"extendida": estratégias de ensino e apredizagememenfermagem. Esc Anna Nery, 9(3):429-33.

Malta DC, Castro AM (2009). Avanços e resultadosnaimplementação da Política Nacional de Promoção da Saúde. Boletimtécnico do SENAC; 35: 6371.

Marques GA, Silva RR, Mata RN, Ribeiro M (2019). FórumConexão dos Saberes: extensãounivers itáriapromovendo o desenvolvimento social. Rev CiencExtensão, 15(2):117-25.

Medina MG, Aquino R, Vilasbôas ALQ, Mota E, Pinto Junior EP, Luz LA, Anjos DSO, Pinto ICM (2014). Promoção da saúde e prevenção de doençascrônicas: o que fazem as equipes de Saúde da Família. Saude Debate, 38:69-82.

Melo Neto JF (2002). ExtensãoUniversitária: bases ontológicas. Extensãouniversitária: diálogospopulares, 113.

Monnerat GL, Souza RG (2011). Da Seguridade Social à intersetorialidade: reflexõessobre a integração das políticassociais no Brasil. R. Katál., 14(1):41-9

Nascimento ARA, Oliveira NFC, Araújo NA, Nonato SP, Fonseca VAC, Santos IF, Maia BO (2018). DocumentoSíntese do $1^{\mathrm{o}}$ CicloAvaliativo do Perfil das Ações de Extensãona UFMG (2014 a 2016).

Oliveira FLB, Almeida Júnior JJ (2015). Extensãouniversitária: contribuiçõesnaformação de discentes de Enfermagem. RevBrasPesqSaude, 17(1):1924.

Pereira FGF, Caetano JA, Moreira JF,Ataíde MBC (2015). Práticaseducativasemsaúdenaformação de acadêmicos de enfermagem. CogitareEnferm, 20(2):332-7.
Ponte CIRV, Torres MAR, Machado CLB, Manfrói WC (2009). A extensãouniversitáriana Famed/UFRGS: cenário de formaçãoprofissional. Rev Bras Educ Med, 33(4):52734.

Sá-Silva JR, Almeida CD,Guindani JF (2009).Pesquisa documental: pistasteóricas e metodológicas. Rev Bras Hist Cienc Soc. 1(1):1-15.

Scliar M (2007). História do conceito de saúde. Physis, 17(1):29-41.

Segre M, Ferraz FC (1997). O conceito de saúde. Rev SaúdePública, v. 31, n. 5, p. 538-42.

Shimazaki ME (2009). A atençãoPrimária à Saúde. MINAS GERAIS. Escola de SaúdePública do Estado de Minas Gerais. Implantação do Plano Diretor da AtençãoPrimária à Saúde. Oficina, 2:10-6.

Silva SED, Vasconcelos EV, Padilha MICS, Martini JG, Backes VMS (2007). A educaçãoemsaúdecom oumaestratégia para enfermagemnaprevenção do alcoolismo. Esc Anna Nery, 11(4):699-705.

Skura I, Velho APM; Francisco CCB (2013). Mídiassociaisdigitais e a terceiraidade: embusca de uma ferramenta para a promoção da saúde. RevistaKairós: Gerontologia, 16(4):237-49.

Soares LT (2012). CT\&I, desenvolvimento social e demandaslocais: o papel da extensãouniversitária. Parc Estrat, 16(32):555-74.

Sobrinho CLN, Nascimento MA, Carvalho FM (2005). Transformações no trabalhomédico. Rev Bras Educ Med, 29(2):129-35.

Tavares DMS, Simões ALA, Poggetto MTD, Silva SR (2007). Interface ensino, pesquisa, extensãonoscursos de graduação da saúdenaUniversidade Federal do TriânguloMineiro. Rev Latino-Am Enfermagem, 15(6):1080-5.

World Health Organization (1998). Health promotion evaluation: recommendations to policymakers. Copenhagen: European Working Group on Health Promotion Evaluation. 